\title{
EFFECT OF THE AQUEOUS EXTRACT OF PSIDIUM GUAJAVA ON ERYTHROMYCIN-INDUCED LIVER DAMAGE IN RATS
}

\author{
N. SAMBO*, S. H. GARBA ${ }^{1}$ AND H. TIMOTHY ${ }^{1}$ \\ Departments of Human Physiology* and Human Anatomy ${ }^{1}$, College of Medical Sciences, University of Maiduguri, \\ Maiduguri, Nigeria. E-mail: nusambo@gmail.com, Tel: 234-08053539124, 234 (0) 7035227211
}

\begin{abstract}
Summary: The effect of Psidium guajava extract on erythromycin-induced liver damage in albino rats was investigated using 30 normal rats grouped into six. Group I and II served as the normal and treatment controls that were administered with normal saline and $100 \mathrm{mg} / \mathrm{kg}$ body weight of erythromycin stearate daily for 14 days respectively. Rats in group III were administered $450 \mathrm{mg} / \mathrm{kg}$ body weight of Psidium guajava only for 7 days while rats in groups IV, V and VI were administered Psidium guajava extract for 7 days and 100mg/kg body weight of erythromycin for 14 days. Histopathological investigation of the liver tissues revealed striking oedema and mild periportal mononuclear cell infiltration of hepatic cords in the liver of rats administered $100 \mathrm{mg} / \mathrm{kg}$ of erythromycin stearate and 300/450 mg/kg of Psidium guajava extract. Pretreatment with $150 \mathrm{mg} / \mathrm{kg}$ of Psidium guajava extract showed a slight degree of protection against the induced hepatic injury caused by $100 \mathrm{mg} / \mathrm{kg}$ of erythromycin stearate. Biochemical analysis of the serum obtained revealed a significant increase in serum levels of hepatic enzymes measured in the groups administered with $100 \mathrm{mg} / \mathrm{kg}$ of erythromycin stearate and $300 / 450 \mathrm{mg} / \mathrm{kg}$ of Psidium guajava extract compared to the control groups and those pretreated with $150 \mathrm{mg} / \mathrm{kg}$ of Psidium guajava extract. This study has shown that the aqueous extract of psidium guajava leaf possesses hepatoprotective property at lower dose and a hepatotoxic property at higher dose but further studies with prolonged duration is recommended. Key words: Psidium guajava, liver, liver enzymes, histology
\end{abstract}

\section{Introduction}

Erythromycin stearate is a macrolide antibiotic which has an anti microbial spectrum slightly wider than that of penicillin and is effective against many gram-positive and gram negative bacteria. It prevents bacterial growth by interfering with their protein synthesis. Erythromycin is actively transported to the site of infection, where during active phagocytosis, large concentration of erythromycin are released and is used in the treatment of pneumonia, tonsillitis, bronchitis, gonorrhea, pelvic inflammatory disease and urinary tract infections. Its main elimination route is the bile and a small portion in the urine and side effects associated with the drug include diarrhea, nausea, abdominal pain, vomiting and massive liver failure.

The plant Psidium guajava is from the familymyrtaceae, it is a small tree about $8 \mathrm{~m}$ high and often cultivated throughout the tropics with the leaves and the fruit been the most used part of the plant is. The long history of guava for medicinal purposes led to the documentation of its properties/actions which includes antioxidant effect which is beneficial to the heart as a cardiprotective agent (Jimenej-Escrig 2002), its analgesic, anti-bacterial, anti-dysenteric, anti-malarial and anti-ulcerous properties has also been documented. Guava has also been used as a cardio depressant, CNS depressant, cough suppressant, hypotensive agent, sedative and a vasoconstrictor. Other properties/action documented by traditional users include: anti-anxiety, anticonvulsant, blood cleanser and a menstrual stimulant. The fruit is still enjoyed as a sweet treat and for medicinal uses by indigenous peoples throughout the rain forest up till today (Gill, 1992).chemical analysis of guava plant extract have revealed the presence of anti-microbial compounds (Arima, 2002), tannins, phenol triterpenes, flavonoids, guajivolic acid, guajavanoic acid, linolenic acid, linoleic acid, guavacoumaric acid, galaturonic acid, asphaltic acid, benzaldehyde, essential oils, saponins, carofenoid, cectin, fibre, fatty acids and a high content of vitamins $\mathrm{C}$ and $\mathrm{A}$ in its fruit (Suntornonk et al 2002). The leaves are rich in flavonoids, (quercetin) attributing for most of its therapeutic activity.

The common names of this plant include guaba in Yoruba, giba in Hausa, gova in Igbo and ugwaba in Efik (Gbile, 1984, Okujagu et al 2005). This study was therefore designed to determine the hepatoprotective effect of psidium guajava on erythromycin induced liver damage in albino rat.

\section{Materials and methods}

Collection and identification of plant materials

The fresh leaves of Psidium guajava where obtained within the University of Maiduguri campus which was identified and authenticated by Dr. S.S. 
N. Sambo et al

Sanusi (Plant Taxonomist) of the Department of Biological Sciences, University of Maiduguri, Borno state. A total of $500 \mathrm{~g}$ of the fresh leaves were harvested and dried at room temperature which was then pulverized into powder using a pestle and mortar.

\section{Preparation of extract}

A total of two hundred and fifty grams of the powdered leaves were boiled in distilled water at $100^{\circ} \mathrm{C}$ resulting in a mean yield of $100.8 \pm 2 \mathrm{~g}$. The extract obtained was concentrated in a water bath until a constant dark sticky residue was obtained, this was further oven dried and maintained in a dessicator until a constant weight was obtained. The dried extract obtained was stored in a tightly stoppered container in a refrigerator at $-4^{\circ} \mathrm{C}$ until required. Stock solution of the extract was prepared by dissolving $5 \mathrm{~g}$ weight of the powdered extract in 50 $\mathrm{mL}$ of normal saline and the concentration used was $0.1 \mathrm{~g} \mathrm{~mL}^{-1}$

\section{Animals and Husbandry.}

This study was carried out in the Departments of Human Anatomy and Physiology, University of Maiduguri between June and October, 2007. A total of 30 male Wister albino rat weighing $100 \mathrm{~g}$ and $210 \mathrm{~g}$ and 3-4 months old were used for the study. The rats were purchased from the animal house of the Department of Pharmacology and Pharmaceutical Sciences, University of Jos, Plateau State, Nigeria. Following an acclimatization period of 2 weeks, the rats were individually identified by color tattoo and weighed. The rats were kept in plastic cages under standard laboratory conditions at room temperature with $12 \mathrm{hrs}$ light/dark cycle with access to standard laboratory diet (Sanders Nigeria Limited, Kaduna) and drinking water ad libitum.

\section{Experimental protocol.}

A total of thirty male Wister albino rats were used in this study, they were weighed and randomly divided into six groups of 5 rats each (I-VI). Group I served as the normal control and were administered normal saline equivalent to the volume administered to the highest dosed experimental rats.Rats in group II served as the treatment control and were administered $100 \mathrm{mg} / \mathrm{kg}$ body weight of erythromycin stearate, for 14 days via oral intubation in order to induce liver damage (Hameid, 2007). Group III was administered psidium guajava extract $(450 \mathrm{mg} / \mathrm{kg}$ body weight) once a day for seven days according to the method of (Hewawasam et al, 2004) via oral intubation. Group IV was administered erythromycin starate $100 \mathrm{mg} / \mathrm{kg}$ body weight and psidium guajava $150 \mathrm{mg} / \mathrm{kg}$ body weight for 14 days and 7 days respectively via oral intubation. Group V received psidium guajava $300 \mathrm{mg} / \mathrm{kg}$ body weight and erythromycin starate $100 \mathrm{mg} / \mathrm{kg}$ for same duration while rats in Group VI receive $450 \mathrm{mg} / \mathrm{kg}$ body weight of psidium guajava and erythromycin starate $100 \mathrm{mg} / \mathrm{kg}$ for the same duration. All the administration (erythromycin stearate and pdisium guajava) were done daily for the whole period (21 days) and then sacrificed.

\section{Biochemical analysis}

Blood collected from the animals through transection of the jugular vein were put into sterile bottles and centrifuged at a rate of 12,000 revolutions per minute (rpm) for $10 \mathrm{~min}$. The clear serum obtained were analyzed for Aspartate transaminase (AST), Albumin, Alanine transaminase (ALT), Alkaline phosphatase (ALP), Conjugated and Total Bilirubin using Randox Laboratory kits at the Department of Chemical Pathology, University of Maiduguri Teaching Hospital Maiduguri.

\section{Histological analysis}

The liver tissue obtained was carefully dissected out, weighed, fixed in Bouins fluid, embedded in paraffin and sectioned at $5 \mu \mathrm{m}$. Sections were stained with Haematoxylin and Eosin and mounted in Canada balsam. Light microscopic examination of the sections was then carried out.

\section{Statistical analysis}

Numerical data obtained from the study were expressed as the mean value \pm standard error of mean. Differences among means of control and treated groups were determined using statistical package (GraphPad Instat). A probability level of less than 5\% $(\mathrm{p}<0.05)$ was considered significant.

\section{Results}

\section{Gross Anatomical Observation}

The liver of the control group showed normal gross features while those of the treatment group administered with erythromycin stearate presented with livers that were enlarged (data not shown).

The effect of the administration of Erythromycin stearate and extract on mean body weight

There was a significant loss in the body weights of the rats administered with erythromycin stearate and a slight loss in body weights of rats administered with both the extract and erythromycin stearate compared to the control group that had a steady weight gain (Table 1.) 
Psidium guajava and erythromycin-induced liver damage

The effect of the administration of the extract and erythromycin on biochemical parameters :

Administration of $100 \mathrm{mgkg}^{-1}$ erythromycin stearate was observed to have caused increases in all parameters with only the serum levels of conjugated and total bilirubin displaying significance $(\mathrm{p}<0.05)$ while albumin level was significantly $(\mathrm{p}<0.01)$ decreased. Administration of $450 \mathrm{mgkg}^{-1}$ of psidium guajava extract alone caused a significant decrease $(p<0.05)$ in the serum levels of ALAT and total protein. Pretreatment with $100 \mathrm{mgkg}^{-1}$ of psidium guajava extract against $100 \mathrm{mgkg}^{-1}$ of erythromycin stearate was able to reverse the hepatoxic effect of the stearate though not to a significant level while pretreatment with 300 and $450 \mathrm{mgkg}^{-1}$ of the extract only potentiated the hepatotoxic effect of erythromycin stearate by the significant increase $(\mathrm{p}<0.05-0.01)$ noticed in all the serum parameters analysed (Table 2).

Histological Findings

Table 1: Effect of the administration of erythromycin and extract on mean body weights

\begin{tabular}{|c|c|c|c|c|c|c|}
\hline \multirow[t]{2}{*}{ Groups } & \multicolumn{2}{|c|}{$\begin{array}{l}\text { Doses administered } \\
\left(\mathrm{mgkg}^{-1}\right)\end{array}$} & \multirow{2}{*}{$\begin{array}{l}\text { Initial body } \\
\text { weight } \\
\text { (g) }\end{array}$} & \multirow{2}{*}{$\begin{array}{c}\text { Final body } \\
\text { weight } \\
\text { (g) }\end{array}$} & \multirow{2}{*}{$\begin{array}{c}\text { Body weight } \\
\text { difference } \\
\text { (g) }\end{array}$} & \multirow[t]{2}{*}{$\begin{array}{c}\text { Weight } \\
\text { change }(\%)\end{array}$} \\
\hline & Extract & Erythromycin & & & & \\
\hline I & 0 & 0 & $168.75 \pm 8.84$ & $180.80 \pm 3.25$ & 12.05 & 6.66 \\
\hline II & 0 & 100 & $208.93 \pm 7.65$ & $202.08 \pm 11.18$ & 6.85 & 3.38 \\
\hline III & 450 & 0 & $176.15 \pm 4.03$ & $205.05 \pm 6.44 *$ & 28.90 & 14.09 \\
\hline IV & 150 & 100 & $149.98 \pm 21.00$ & $193.03 \pm 25.72 *$ & 43.05 & 22.30 \\
\hline $\mathrm{V}$ & 300 & 100 & $130.15 \pm 11.95$ & $158.05 \pm 15.63$ & 27.90 & 17.65 \\
\hline VI & 450 & 100 & $209.03 \pm 16.78$ & $223.00 \pm 28.17$ & 13.97 & 6.26 \\
\hline
\end{tabular}

Table 2: Effect of the administration of erythromycin stearate and extract on biochemical parameters

\begin{tabular}{|c|c|c|c|c|c|c|c|c|c|}
\hline \multirow[t]{2}{*}{ GROUPS } & \multicolumn{2}{|c|}{ Doses administered $\mathrm{mgkg}^{-1}$} & \multirow{2}{*}{$\begin{array}{l}A S A T \\
I U / L\end{array}$} & \multirow{2}{*}{$\begin{array}{c}A L A T \\
I U / L\end{array}$} & \multirow{2}{*}{$\begin{array}{l}A L P \\
I U / L\end{array}$} & \multirow{2}{*}{$\begin{array}{l}T P \\
g / L\end{array}$} & \multirow{2}{*}{$\begin{array}{c}A L B \\
M m o l / L\end{array}$} & \multirow{2}{*}{$\begin{array}{c}C . B \\
M m o l / L\end{array}$} & \multirow{2}{*}{$\begin{array}{c}T . B \\
\mathrm{Mmol} / \mathrm{L}\end{array}$} \\
\hline & extract & erythromycin & & & & & & & \\
\hline $\mathrm{I}$ & 0 & 0 & $\begin{array}{c}91.0 \pm \\
5.44\end{array}$ & $\begin{array}{c}42.0 \pm \\
1.00\end{array}$ & $\begin{array}{c}48.0 \pm \\
8.00\end{array}$ & $\begin{array}{c}80.5 \pm \\
050\end{array}$ & $\begin{array}{c}38.5 \pm \\
0.50\end{array}$ & $\begin{array}{l}5.5 \pm \\
0.50\end{array}$ & $3.5 \pm 0.50$ \\
\hline II & 0 & 100 & $\begin{array}{c}113.75 \pm \\
5.44\end{array}$ & $\begin{array}{c}48.0 \pm \\
0.91\end{array}$ & $\begin{array}{l}86.0 \pm \\
9.33\end{array}$ & $\begin{array}{c}78.25 \pm \\
1.75\end{array}$ & $\begin{array}{l}32.5 \pm \\
0.65 * *\end{array}$ & $\begin{array}{l}8.0 \pm \\
0.41 *\end{array}$ & $\begin{array}{c}5.25 \pm \\
0.48 *\end{array}$ \\
\hline III & 450 & 0 & $\begin{array}{c}99.5 \pm \\
1 . .50\end{array}$ & $\begin{array}{c}39 \pm \\
2.04 *\end{array}$ & $\begin{array}{c}108 \pm \\
9.42\end{array}$ & $\begin{array}{c}63.75 \pm \\
5.63 *\end{array}$ & $\begin{array}{c}30.25 \pm \\
2.25\end{array}$ & $\begin{array}{c}8.25 \pm \\
0.63\end{array}$ & $5 . \pm 0.41$ \\
\hline IV & 150 & 100 & $\begin{array}{c}121.5 \pm \\
7.86\end{array}$ & $\begin{array}{c}56 \pm \\
2.04 *\end{array}$ & $\begin{array}{c}108 \pm \\
2.04\end{array}$ & $\begin{array}{c}63.75 \pm \\
5.63 *\end{array}$ & $\begin{array}{c}.30 .25 \pm \\
2.25\end{array}$ & $\begin{array}{l}8.25 \pm \\
0.63\end{array}$ & 5. \pm 041 \\
\hline V & 300 & 100 & $\begin{array}{l}194.5 \pm \\
0.50 * *\end{array}$ & $\begin{array}{c}79 \pm \\
7.00 * *\end{array}$ & $\begin{array}{c}162 \pm \\
1.55 * *\end{array}$ & $\begin{array}{c}84.5 \pm \\
1.50\end{array}$ & $\begin{array}{c}31.5 \pm \\
0.50\end{array}$ & $\begin{array}{l}9.5 \pm \\
0.50\end{array}$ & $7.5 \pm 0.50 *$ \\
\hline VI & 450 & 100 & $132 \pm 2.00$ & $\begin{array}{c}61 \pm \\
1.00 * *\end{array}$ & $\begin{array}{c}134.5 \pm \\
1.50 *\end{array}$ & $\begin{array}{c}66 \pm \\
6.00 *\end{array}$ & $\begin{array}{c}35.5 \pm \\
0.50 *\end{array}$ & $\begin{array}{l}8.5 \pm \\
0.50\end{array}$ & $4.5 \pm 0.50$ \\
\hline
\end{tabular}

Significance relative to control (Group I) $*=\mathrm{P}<0.05, * *=\mathrm{P}<0.01, * * *=\mathrm{P}<0.001$, Significance relative to group IV (300 $\left.\mathrm{mgkg}^{-1}\right) \mathrm{a}=\mathrm{p}<0.05, \mathrm{~N}=5$ Results are presented as Means $\pm \mathrm{SEM}$. ASAT $=$ Aspartate Aminotransaminases, ALAT $=$ Alanine Aminotransaminases, $\mathrm{ALP}=$ Alkaline Phosphatase, $\mathrm{ALB}=$ Albumin, $\mathrm{TP}=$ Total protein and $\mathrm{CB}=\mathrm{Conjugated}$ Bilirubin 
N. Sambo et al

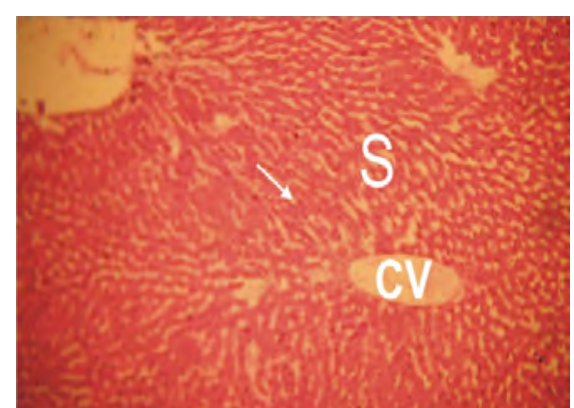

Fig. 1: Micrograph of the liver of a control rat showing normal liver parenchyma with Central vein $(V)$ and Sinusoids (S) H and E stain. Mag. $x 100$

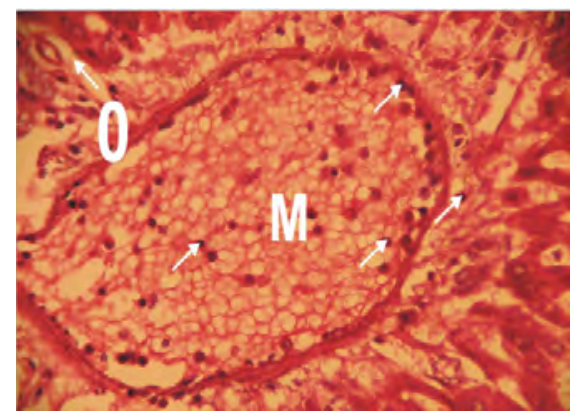

Fig 2: Micrograph of the liver of a rat administered 100 $\mathrm{mgkg}^{-1}$ of erythromycin showing stricking edema $(O)$ and periportal mononuclear infiltration( $M)$ and sinusoid $(S) H$ and E stain. Mag. x 200

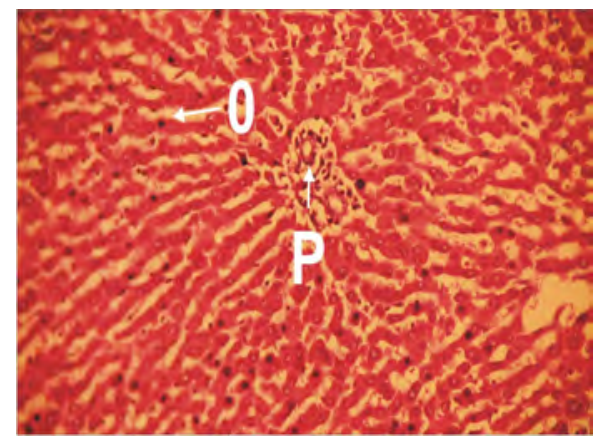

Fig 3: Micrograph of the liver of a rat administered 450 $m \mathrm{~kg}^{-1}$ of the aqueous extract of psidium guajava showing mild edema $(O)$, hepatic cord $(H)$ and portal triad $(P) H$ and E stain. Mag. $x 400$

\section{Discussions}

The study was designed to study the effect of psidium guajava extract on erythromycin induced liver damage in rats. The loss of body weight observed in the groups administered erythromycin together with psidium guajava extract when compared with the rats in the control group that were administered only normal saline might be attributed to the loss of appetite observed during the course of the study which might have led to decrease in food intake or lesions in the intestine leading to malabsorption (Rabo, 1998).

It has been shown that erythromycin stearate caused increase in the levels of plasma enzymes (aspartate aminotransferase and alanine aminotransferase), total bilirubin and hepatomegaly in the liver (Hameid, 2007) ALAT and ASAT are liver enzyme whose levels increase due to release of enzymes from damaged hepatocytes.

The results of this study showed that the administration of erythromycin to rats caused an increase in the levels of ALAT, ASAT, Alkaline Phosphatase and Bilirubin, but the increase was only significant for ALAT. Alkaline phosphatase levels increase remarkably in diseases "that impair bile formation and to a lesser extent in hapatocellular diseases.

For the groups administered $150 \mathrm{~kg} / \mathrm{kg}$, $300 \mathrm{mg} / \mathrm{kg}$ and $450 \mathrm{mg} / \mathrm{kg}$ of extract and erythromycin $(100 \mathrm{mg} / \mathrm{kg})$, there was significant increase in the levels of ALAT, ASAT, ALP and total protein $(\mathrm{P}<0.05)$. This elevation was seen to be more at a dose of $300 \mathrm{mg} / \mathrm{kg}$ and $450 \mathrm{mg} / \mathrm{kg}$ thus indicating hepatotoxicity of the liver. ALAT is liver specific and thus any increase in its level is a clear indicator of injury to the hepatocytes of the liver. (Ellis et al 1978). At low dose, there were insignificant increases in the level of this parameter indicating a decreased hepatotoxicity of the liver i.e. an anti hepatotoxic affect of the extract this effect may be due to the presence of flavonoids in the extract which are said to be hepatoprotective (Trease and Evans 1989), this findings agrees with earlier works of Sai et al (1998) using the green tea (Camelia simensis) which attributed the hepatoprotection observed in their study to the presence of polyphenols considered to be bioflavonoids which in turn is a sub category of the larger group of polyphemol (Tey et al 1988). A possible mechanism of action of psidiumm guajava as hepatoprotective agent could be through its antioxidant activity. Oedema in this result denotes excess plasma fluid in the interstitium which normally causes an expansion in the intracellular matrix and a major local manifestation of acute inflammation in dividing resident of lymphocytes or macrophages (Kumar,et al 2004).

It observed in this study, that administration of erythromycin causes liver damage in the rats which is characterized by edema and periportal mononuclear infiltration of inflammatory cell which agrees to a similar work by Hameid (2004) that established the role of erythromycin stearate as a hepatotoxin. The experimental groups administered the various dose of the extract and erythromycin stearate showed 
Psidium guajava and erythromycin-induced liver damage

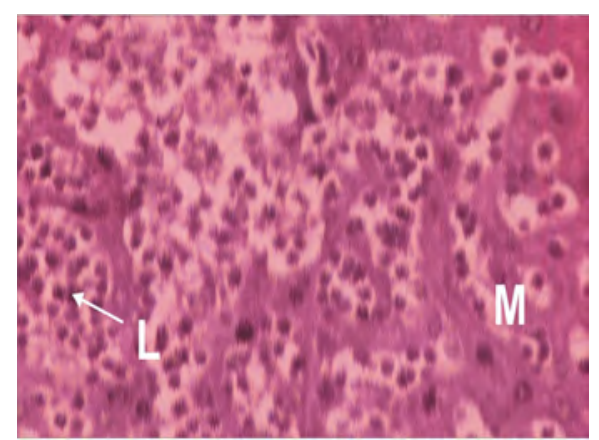

Fig 4: Micrograph of the liver of a rat administered 150 $\mathrm{mgkg}^{-1}$ of the aqueous extract of psidium guajava and 100 mgkg ${ }^{-1}$ of erythromycin showing slight hepatoprotection with aggregates of lymphocytes $(L)$, periportal mononuclear infiltration (M) H and E stain. Mag. $x 400$

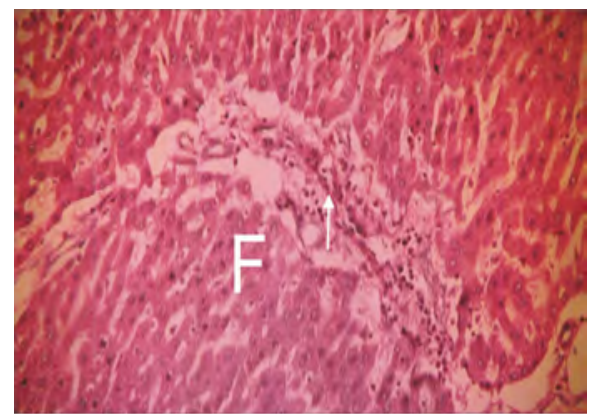

Fig 5: Micrograph of the liver of a rat administered $300 / 450 \mathrm{mgkg}^{-1}$ of the aqueous extract of psidium guajava and $100 \mathrm{mgkg}^{-1}$ of erythromycin showing mild edema $(O)$ and fibrosis $(F) H$ and $E$ stain. Mag. $x 400$.

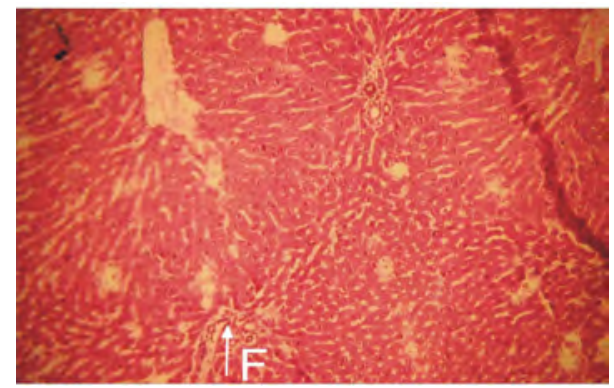

aggregate of lymphocyte, infiltration of macrophages around the portal triad, mild edema and portal triad with fibrosis an indication of liver damage. The histomorphology of the liver administered lower doses of the extract $(150 \mathrm{mg} / \mathrm{kg})$ showed slight hepatoprotection as compared to the group administered with medium and high dose of the extract $(300 \mathrm{mg} / \mathrm{kg}$ and $450 \mathrm{mg} / \mathrm{kg})$ thus complementing the result obtained from serum biochemical analysis.
This study has shown that the aqueous extract of psidium guajava leaf possesses hepatoprotective property at lower dose and a hepatotoxic property at higher dose but further studies with prolonged duration is recommended.

\section{Acknowledgement}

We wish to acknowledge the technical assistance of Ibrahim Wiam and Ephraim Ayuba of the Departments of Veterinary Anatomy and Human Anatomy, University of Maiduguri, Nigeria.

\section{References}

Arima, H, (2002). Isolation of Antimicrobial Compound from guava (Psidium guajava) and their structural elucidation Biosci. Biochem 66 (8): $1727-30$

Ellis, G., Goldberg, D. M., Spooner R. J, (1978). Certain enzyme text in disease of the liver. Am. J. Clin . Pathol. 70: 248-258.

Gbile, Z. O. (1984). Vernacular names of Nigerian plants; Yoruba forestry research institute of Nigeria Ibadan in: Okujagu, T.F. (2005). Book of abstract of published Research finding on Nigerian Medicinal plant and traditional medicine practice 1: 132.

Gill, L, S (1992): Ethno-medical uses of plant in Nigeria; University of Benin press Benin City. In: Okujagu T.F. (2005). Book of abstract of published Research finding on Nigerian Medicinal plant and traditional medicine practice. 1: $131-132$.

Hameid, N. A. (2007). Protective role of dimethyl diphenyl bicarboxylate (DDB) against erythromycin induced hepatotoxicity in male rat. Toxicol in Vitro. 21(40): 618-625.

Hewawasam, R. P., Jayatilaka, K. A. P. W., Pathirana, C. and Mudduwa, L. K. B. (2004). Hepatoprotective effect of Epaltes divaricata extract on carbon tetrachloride induced hepatotoxicity in mice. Indian J Med Res. 120(1): 30-34.

Jimenej-Escrig, A. (2002). Guava fruit (Psidium Guajava L.) as a new source of antioxidant Dietary fiber. J. Agric. Food. Chem. 49(11): 5489-93.

Kumar, Abbas, A. K. Fausto, N. (2004). Robbins and Cotran Pathologic Basis of Disease. $7^{\text {th }}$ ed. Saunders Elsevier, Philadelphia, pp. 48-51.

Okujagu, T. F., Etatuvie Sam O., Ifeyinwa E., Jimoh B., Nwokeke (2005). Book of abstract of published Research finding on Nigerian Medicinal plant and traditional medicine practice. 1: 90.

Rabo, J. S. (1998). Toxicity studies and trypanosuppressive effect of stem- back extract of Buturospermum and paradoxin, in Laboratory 
N. Sambo et al

animals. Ph.D. Thesis, Department of Veterinary Pathology University of Maiduguri,Nigeria. pp: 15-50.

Sai, K., Kai, S., Umemura, T., Tanimura, A, Hasegawa, R., Inoue, T. and Kurokawa, Y. (1998). Protective effect of green tea on hepatotoxicity, oxidative DNA damage and cell proliferation in the rat liver induced by repeated oral administration of 2-nitropropane. Food Chem Toxicol. 36(12): 1043-1051.
Suntornsuk, L. (2002). Quantitation of vitamin C content in herbal juice using direct titration. $J$. Pharm. Biomed. Anal. 28(5 : 849 -855.

Trease, G. E. and Evans, W. C. (1989). Phamarcognosy $13^{\text {th }}$ Ed. London UK. English Language Book Society. Bailierre Tindall. Pg 832.

Received: September 4, 2009

Accepted: November 24, 2009 